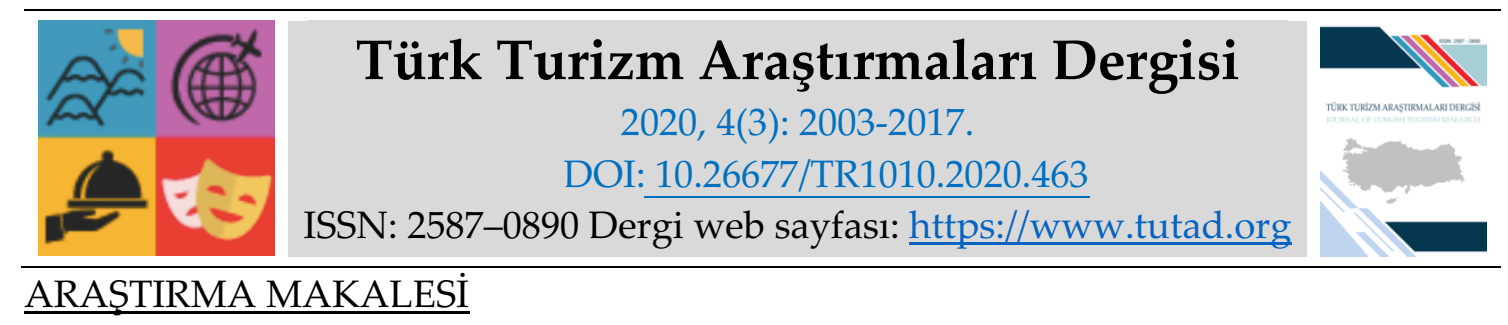

\title{
Potansiyel Turizm Destinasyonlarında Bulunan Otellerle İlgili E-Şikâyetlerin Coğrafi Bakışla Değerlendirilmesi: Adıyaman Örneği
}

Arş. Gör. Dr. Hülya YEŞiLYURT, Adıyaman Üniversitesi, Turizm Fakültesi, Adıyaman, eposta: hyesilyurt@adiyaman.edu.tr

ORCID: https://orcid.org/0000-0002-9991-2557

Dr. Öğr. Üyesi Caner ÇALIŞKAN, Adıyaman Üniversitesi, Turizm Fakültesi, Adıyaman, eposta: ccaliskan@adiyaman.edu.tr

ORCID: https://orcid.org/0000-0002-7774-1769

Dr. Öğr. Üyesi Çinuçen OKAT, Van Yüzüncü Yıl Üniversitesi, Turizm Fakültesi, Van, e-posta: cinucenokat@yyu.edu.tr

ORCID: https://orcid.org/0000-0002-1335-0216

Öz

Günümüz turizm sektöründe hizmet sunumunu daha eleştirilebilir kılan sanal dünya, bu hizmetleri deneyimlemiş müşterilerin yorumlarını ve şikâyetlerini potansiyel tercih kitlesinin parametresi yapmaktadır. Özellikle sektörün dinamosu olan otel işletmeleri için söz konusu şikâyetler başlıca belirleyiciler arasında yer almaktadır. Diğer yandan bu durum, sektörel gelişme sürecinde olan ve bulunduğu coğrafyanın algılanma düzleminden dolayı nispeten rekabetin gölgesinde kalan bölgelerdeki oteller için farklı bir anlam kazanmaktadır. Buradan hareketle eşikâyet konusu, turistik gelişme sürecinde bir il olan Adıyaman özelinde ve coğrafi bakış ekseninde ele alınmıştır. Örneklem olarak etkileşimi yüksek seyahat platformlarının başında gelen TripAdvisor sitesi alınmış ve veriler sitede yer alan müşteri yorumlarından elde edilmiştir. Yerli ve yabancı müşteriler tarafından yapılan 13 otel işletmesine ait "ortalama", "kötü" ve "berbat" sınıflamasındaki 137 yorum; doküman incelemesi, içerik analizi ve betimsel analiz teknikleri ile incelenmiştir. Elde edilen bulgular doğrultusunda en fazla şikâyet konusu yiyecekiçecek temasında belirmiştir. En sık tekrarlanan şikâyet içerikleri ise kahvaltı çeşitliliği, yiyecek kalitesi, oda tasarımı, oda temizliği ve bakımı esasında şekillenmiştir. Çalışmada incelenen yorumlara yönelik işletmelerin geri dönüş oranının ise \%35 olduğu saptanmıştır.

Anahtar Kelimeler: Otel işletmeleri, Adıyaman, E-Şikâyet, TripAdvisor.

Makale Gönderme Tarihi: 03.03.2020

Makale Kabul Tarihi: 06.07.2020

Önerilen Atıf:

Yeşilyurt, H., Çalışkan, C. ve Okat, Ç. (2020). Potansiyel Turizm Destinasyonlarında Bulunan Otellerle İlgili E-Şikâyetlerin Coğrafi Bakışla Değerlendirilmesi: Adıyaman Örneği, Türk Turizm Araştırmaları Dergisi, 4(3): 2003-2017.

(C) 2020 Türk Turizm Araştırmaları Dergisi. 


\title{
Journal of Turkish Tourism Research
2020, 4(3): 2003-2017.
DOI: 10.26677/TR1010.2020.463 \\ RESEARCH PAPER
}

\section{Evaluation of E-Complaints about Hotels in Potential Tourism Destinations with a Geographical View: The Example of Adıyaman}

Dr. Hülya YEŞILIYURT, Adıyaman University, Faculty of Tourism, Adıyaman, e-mail: hyesilyurt@adiyaman.edu.tr ORCID: https://orcid.org/0000-0002-9991-2557

Assistant Prof. Dr. Caner ÇALIŞKAN, Adıyaman University, Faculty of Tourism, Adıyaman, email: ccaliskan@adiyaman.edu.tr ORCID: https://orcid.org/0000-0002-7774-1769

Assistant Prof. Dr. Çinuçen OKAT, Van Yüzüncü Yıl University, Faculty of Tourism, Van, e-mail: cinucenokat@yyu.edu.tr ORCID: https://orcid.org/0000-0002-1335-0216

\begin{abstract}
The virtual world, which makes service delivery more criticized in today's tourism sector, makes the comments and complaints of customers who have experienced these services a parameter of the potential choice group. Especially for hotel businesses, which are the dynamo of the sector, these complaints are among the main determinants. On the other hand, this situation has a different meaning for the hotels in the regions that are in the process of sectoral development and in the shadow of the competition due to the perception level of the geography in which they are located. From this point of view, the subject of ecomplaint is handled in Adiyaman, a province in the process of tourist development, and in the geographical point of view. As a sample, TripAdvisor site, which is one of the most interactive travel platforms, was taken and the data was obtained from the customer comments on the site. 137 comments in the "average", "bad" and "terrible" classification of 13 hotel businesses made by domestic and foreign customers; were examined by using document review, content analysis and descriptive analysis techniques. In line with the findings obtained, the most common complaint appeared in the theme of food and beverage. The most frequently recurring complaint contents were shaped on the basis of breakfast variety, food quality, room design, room cleaning and maintenance. The return rate of the enterprises for the comments examined in the study was found to be $35 \%$.
\end{abstract}

Keywords: Hotels, Adıyaman, E-Complaint, TripAdvisor.

Received: 03.03.2020

Accepted: 06.07.2020

\section{Suggested Citation:}

Yeşilyurt, H., Çalışkan, C. and Okat, Ç. (2020). Evaluation of E-Complaints about Hotels in Potential Tourism Destinations with a Geographical View: The Example of Adiyaman, Journal of Turkish Tourism Research, 4(3): 2003-2017.

(C) 2020 Türk Turizm Araştırmaları Dergisi. 


\section{GİRIŞ}

Sınırları ortadan kaldıran sanal dünyanın yükselişi ve beraberinde genişleyen küresel iletişim kapasitesi, olumlu-olumsuz deneyimlerin paylaşıldığı şikâyet sitelerinin artışına yol açmıştır (Harrison-Walker, 2001). Yaygin bir etkiye sahip olması ile birlikte, bu mecralarda yer alan müşteri yorumları, potansiyel müşteriler için artık birer referans noktası haline gelmiş ve bir anlamda işletmeler ile hedef kitleleri arasında sanal bir köprü oluşturmuştur (Buhalis ve Law, 2008; Yaşar, 2019). Bilgi ve iletişim teknolojilerinin hegemonyası, her sektörde olduğu gibi turizm sektöründe de sürmektedir. Esasen turizm, anlam bakımından soyut ve deneyime muhtaçtır. Bu noktada deneyimlerin yorumlandığı bu sanal vitrinler, her ne kadar öznel olsa da çoğu potansiyel kitle için gidilmek istenen destinasyonlar, oteller veya restoranlar için gerçeğe en yakın fikri veren ve bu anlamiyla algisal riski azaltan bir rol üstlenmektedir (Zeng vd., 2020). Bununla birlikte, sanal ortamda bulunan olumlu yorumlar işletmeler için ucuz ve etkili bir pazarlama firsatı sunarken, olumsuz eleştiriler (veya e-şikâyetler) müşteri ve imaj kaybına neden olabilmektedir (Alrawadieh ve Dinçer, 2019; O'Connor, 2010).

E-şikâyet konusu, turizm sektörünün sacayaklarından oteller için ayrıca önem atfetmektedir. Müşteri şikâyetleri, bir yandan otellerin hizmet kalitesi veya rekabet güçleri ile ilgili hataların saptanmasını sağlarken (Kılıç ve Ok, 2012) diğer yandan işletmelerin kapanmasına değin büyük sorunlara yol açabilmektedir (Kutluk ve Arpacı, 2016). Daha özelde bu durum, sektörel gelişme sürecinde olan ve rakiplerine göre dezavantajlı bölgelerde bulunan otelleri daha kaygan bir zemine itmektedir. Bulunduğu coğrafyanın algılanma düzleminden dolayı, hizmet kalitesini daha yüksek tutması gereken bu oteller için ilgili sitelerde yer alan yorumlar, potansiyel müşterilerin zihninde organik bir imaj çizmektedir. Çalışkan ve Dedeoğlu'na (2018) göre coğrafya ve turizm bir bütündür. Bir yerin coğrafyası aynı zamanda o yerin cazibe unsuru ve rekabet kozu olabilmektedir. Dolayısıyla algısal etkisi ve işlevi düşünüldüğünde, sanal dünyada yapılan yorumlar (Şahin vd., 2017), coğrafi açıdan rekabetin gölgesinde kalmış oteller için belirleyici olabilmektedir. Buradan hareketle, çalışmanın veri çerçevesini Adıyaman'da bulunan oteller oluşturmaktadır. Potansiyel bir turizm destinasyonu olarak Adıyaman, sektörel gelişme düzleminde gerek fiziki gerekse algı eksenli engellere sahip bir coğrafyada konumlanmıştır (Yılmaz ve Çalışkan, 2015). Bağlı olarak burada bulunan oteller hakkında sanal mecralarda yer alan e-şikâyetlerin mevcut ve potansiyel müşteri kitlesine başlıca referans noktası olduğu düşünülmektedir. Bu kapsamda araştırmada, sosyal etkileşimi yüksek olan TripAdvisor sitesinde, ilgili oteller hakkında yer alan e-şikâyetlerin analizi ve yorumu yapılmış ve öneriler sunulmuştur. Potansiyel bir turizm destinasyonunda bulunan otellerin seçilmesi ve sonuçların coğrafi bakışla ele alınması bakımından çalışmanın benzerlerinden farklılaştığı ve literatüre katkı sağlayacağı düşünülmektedir.

\section{Kavramsal Çerçeve Şikâyet Davranışı}

Şikâyet kavramı, memnun edici olmayan bir deneyim sonucunda oluşan duygusal bir yansıma veya tepki olarak yorumlanabilir (Çakıcı ve Güler, 2015:220). Şikayet davranışı ve bu davranışa iten motivasyonlar karmaşık, dinamik ve değişken bir yapı barındırmaktadır (Heung ve Lam, 2003; Tronvoll, 2007). Farklı şekillerde oluşabilen bu davranış, kimi zaman deneyim odağının artık tercih edilmemesi veya bu deneyimin birçok kişiye yayılması şeklinde gerçekleşebilmektedir (Akan ve Kaynak, 2008:3; Çakıcı ve Güler, 2015). Bir ürün veya hizmet deneyimi ile ilgili şikayet davranışı; katlanılan maliyet, beklenti ve nitelik gibi faktörlerle doğrusallık taşıyabilmekte (Broadbridge ve Marshall, 1995) veya kültürlere göre farklılık gösterebilmektedir (Ngai vd., 2007). Kim ve Lynn'e (2007) göre, şikayet davranışı homojen olmamakla birlikte, kişisel veya sosyo-demografik özelliklere bağlı olarak değişebilmektedir. Bu noktada, memnun olmayan bir tüketici, tahmini zor tepki türlerini benimseyebilmektedir. 
Dolayısıyla birey-deneyim paradigması çerçevesinde şikayet davranışı, işletmelerin dikkate alması gereken güçlü bir işaret olmaktadır. Nitekim bir yandan, işletmeye müşteriyi elde tutmak için son bir şans verirken, diğer yandan tüketiciye karşı meşru bir cevap kanalı sağlamaktadır (Crie, 2003). Anlaşılacağı üzere şikâyet davranışı ile oluşan tablo, verilen hizmetlerin iyileştirilmesi için somut bir geri bildirim ve aynı zamanda müşteri memnuniyetini sağlamada önemli bir fırsat olmaktadır (Arpacı, 2016; Chan vd., 2016:46; Yaşar, 2019).

\section{Beklentinin ve Şikâyetin Öznesi: Oteller}

Oteller, geçici konaklamanın dışında eğlence, konfor gibi isteklerin veya psikolojik tatmin gibi duyguların karşılandığı kurumsal yapılardır (Oral, 2005; Şener, 2010; Özel, 2012). Diğer ifade ile bir otel; adı, logosu veya sahip olduğu odalardan daha fazlasıdır (Chai ve Hobson, 2004: 197). Otellerin sahip olduğu anlamla birlikte, günümüz müşteri kitlesinin daha bilinçli, eğitimli, gelir düzeyi yüksek ve bağlı olarak yenilik arayan bir yapıda olduğu bilinmektedir (Hackett ve Melia, 2012). Dolayısıyla müşterilerin tüketim dünyasının kronik baskısıyla otelleri daha kaliteli bir hizmet anlayışına zorladığı düşünülmektedir (Erdem, 2010). Sınırları bulanık olan müşteri talebinin bu görüntüsü açıkçası otellerde sunulan hizmetlerin yorumunu keskinleştirmektedir. Aynı durumun kendini, müşteri şikâyetlerinin kolay, esnek ve değişken akışıyla gösterdiği söylenebilir. Buna neden olarak otellerin sunmuş oldukları hizmetlerin fiziki kanıttan öte algısal değerle ölçülmesi (Kılıç vd., 2013) gösterilebilir. Benzer söylemle, oteller farklı insanlar tarafından farklı şekillerde algılanan hizmetler sunmaktadır. Bu yüzden her zaman beklentilerle eşleşmeyen hizmetler, müşteri memnuniyetsizliğine ve potansiyel şikâyetlere yol açabilmektedir. Bu noktada, müşteri şikâyetine yol açan unsurları anlamak hem teorik hem de pratik açıdan kritik öneme sahiptir (Ngai vd., 2007). Tyrrell ve Woods (2004), müşterilerine oldukça özen gösteren işletmelerin bile ufak bir servis hatası ile beklenmedik durumlarla karşılaşabileceğini ifade ederken, müşteri şikâyetiyle başa çıkma dilinin önemi üzerinde durmaktadır. Açıkçası günümüzün değişken talep yapısı bireyleri sadık müşteri görüntüsünden uzaklaştırırken bu durum özellikle hizmet hatalarına daha duyarlı müşterilerin şikâyetlerini değerli kılmaktadır (Çulha vd., 2009).

Otel işletmeleri ile ilgili şikayet davranışı yeni sayılmamakla birlikte (Tyrrell ve Woods, 2004), eşikâyetleri konu edinen birçok araştırmanın olduğunu söylemek mümkündür (Arpac1, 2016; Dalgıç vd., 2016; Genç ve Batman, 2018; Kutluk ve Arpacı, 2016). Çulha vd.'nin (2009) Türkiye' deki otel işletmelerine yönelik e-şikâyetleri inceledikleri bir çalışmada, yiyecek-içecek hizmetleri ve odalar başlıca şikâyet konuları olmuştur. O'Connor'ın (2010) Londra'da faaliyet gösteren 100 otel işletmesine ait yorumları incelediği çalışmada; otelin konumu, odaların boyutu ve hizmet kalitesi odak unsurlar olmuştur. Alrawadiech ve Demirkol (2015), İstanbul'da yüksek fiyatlı otel işletmelerine yönelik şikâyet yönetimi ile ilgili yaptıkları bir araştırmada hizmet kalitesi, personel tutumu ve performansı öncelik kazanmıştır. Bayram'ın (2018) bir çalışmasında Tripadvisor'da yer alan en iyi 10 otel işletmesine ait çevrim içi yorumlar incelemiştir. Yazar çalışmasında; odaları, çalışanları, yiyecek-içecekleri, sosyal aktiviteleri, otel konumunu ve peyzaj düzenlemesini müşteri memnuniyetini etkileyen başlıca unsurlar olarak saptamıştır. Fernandes ve Fernandes'in (2018) Portekiz'de bulunan otel işletmeleri ile ilgili e-şikâyetleri inceledikleri çalışmalarında, en fazla şikâyetin müşteri hizmetleri konusunda olduğu görülmüştür. Genç ve Batman (2018), tarihi konak işletmelerine yönelik e-şikâyetleri inceledikleri araştırmalarında şikâyet içeriklerinin daha çok oda, yemek ve çalışanlar üzerinde yoğunlaştığını belirtmişleridir. İstanbul' da beş yıldızlı otel işletmelerine yönelik yapılan bir diğer çalışmada ise şikâyetler ağırlıklı olarak odalar, personel ve ön büro hakkında gerçekleşmiştir (Ak ve Kızılırmak, 2019). Kızıldemir vd. (2019) Afyonkarahisar'daki beş yıldızlı otel işletmelerine yönelik yaptıkları çalışmada, müşteri şikâyetlerini yiyecek-içecek, hizmet kalitesi, oda, çalışanlar, fiyat ve temizlik olmak üzere altı ana tema altında incelerken, yiyecek-içecek hizmetleri ile hizmet kalitesi öne çıkan faktörler olmuştur. 
Doğancili vd. (2019) tarafından Göller yöresinde yapılan bir araştırmada ise temizlik, çalışanlar, yemek, fiyat ve odalar şikâyet nedenlerinin başında gelmiştir.

Literatürde yer alan çalışmalarda, şikâyet konularının yanında bu şikâyetlere yönelik geri bildirimler üzerinde de durulmuştur. Alrawadieh ve Demirkol (2015), otel işletmeleri tarafından e-şikâyetlerin \%42'sine dönüş yapıldığını ortaya koymuşlardır. Dinçer ve Alrawadieh (2017), eşikâyetlerin yaklaşık \%43'ünün otel işletmeleri tarafından cevaplandığını tespit etmişlerdir. Ak ve Kızılırmak (2019) ile Şahin vd. (2017) yaptıkları çalışmalarda ise otel işletmelerinin eşikâyetlerine $\% 90$ oranında geri dönüş yapıldığı saptanmıştır.

Kısaca, otel işletmeleri ile ilgili müşteri şikâyetleri farklı başlık ve içeriklere sahip olurken, bu şikâyetlere yapılan geri dönüşlerin oranı değişkenlik göstermektedir. Bu bağlamda şikâyetlerin ilgili başlıklar esasında analizi, müşterilerin söz konusu otellerle ile ilgili alg1 ve beklenti düzeylerinin yorumunda faydalı olacaktır.

\section{YÖNTEM}

$\mathrm{Bu}$ çalışma, turizm potansiyeli taşıyan ancak coğrafi açıdan rekabetin gölgesinde kalmış Adıyaman'daki otel işletmelerine yönelik e-şikâyetlerin analizini içermektedir. Araştırmanın coğrafi açıdan rekabetin gölgesinde kalmış destinasyon evreninde, Adıyaman örnekleminde gerçekleştirilmiştir. Veriler, TripAdvisor'dan sağlanmıştır.

Verilerin toplanma şeklinde iki dayanak bulunmaktadır: Birincisi; TripAdvisor gibi yüksek etkileşimli web 2.0 teknolojileri ile daha çok müşteri deneyim esasında bilgi üretmekte ve bu deneyimi geniş kitlelere duyurarak etki alanı oluşturmaktadır (Chang vd., 2019). İkincisi; Adıyaman'da geceleme sayısı oldukça az olup (IKA, 2018), müşterilerle yüz yüze görüşme yöntemi ile bilgi toplanması mümkün olmamıştır. Nitekim söz konusu sitedeki verileri toplamak amacıyla belirli bir konu hakkında yazılı materyallerin analizini kapsayan ve zaman tasarrufu sağlayan doküman incelemesi (Şimşek, 2009) yapılmıştır. Bu kapsamda yerli ve yabancı müşteriler tarafından yorum yapılan 13 otel işletmesine ait "ortalama", "kötü" ve "berbat" sinıflamasındaki 137 yorum, 05.01.2020-08.01.2020 tarihleri arasında incelenmiştir.

Analiz sürecinde ilk olarak, içerik analizi ile belirli başlıklar altında bir araya getirilen ifadeler tekrarlanma sayılarına göre sıralanmıştır (Yıldırım ve Şimşek, 2011). Bu noktada, "Kullanıcıların Otel İşletmelerine Yönelik Genel Değerlendirmeleri" ve "E-Şikâyet Unsurlarının Temalara Göre Dağılımı" yapılmıştır. E-şikayet unsurlarının temalara göre ayrımı yapılırken literatürde yer alan çalışmalardan yararlanılmıştır. İkinci olarak; betimsel analiz ile kullanıcı yorumları belirli temalara göre sınıflanmış ve aslına sadık kalınarak ifade haline getirilmiştir (Braun ve Clarke, 2006; Kümbetoğlu, 2008). Bu bağlamda temalar; yiyecek-içecek odalar, genel özellikler, çalışan davranışları, diğer hizmetler ve fiyat şeklinde sınıflanırken temaların ilgili literatürle örtüştüğü (bkz. Çulha vd., 2009; Alrawadiech ve Demirkol, 2015; Bayram, 2018) düşünülmektedir. Analizlerde son olarak müşteri yorumlarına yapılan geri dönüşler incelenmiştir.

\section{BULGULAR}

\section{İçerik Analizi ile Elde Edilen Bulgular}

Tablo 1'de kullanıcıların otel işletmelerine yönelik genel değerlendirmeleri yer almaktadır. Yorumların 333'ü $(\% 70,6)$ mükemmel ve iyi puan değerlendirmesinde olan ve genel olarak memnuniyet içerikli sayılabilecek yorumlardan oluşmaktadır. Bu yorumlar olumlu olduğu düşünülerek ayrıntılı şekilde incelenmemiştir. Sadece sayısal olarak yer verilmiştir. Şikâyet içerikli olduğu düşünülen ortalama, kötü ve berbat olarak puanlandırılan $139(\% 29,4)$ yorum tek tek incelenmiş ve şikâyet unsurları belirlenmiştir. 
Tablo 1. Kullanıcıların Otel İşletmelerine Yönelik Genel Değerlendirmeleri

\begin{tabular}{|l|l|l|l|l|l|l|}
\hline Otel adı & Mükemmel & İyi & Ortalama & Kötü & Berbat & Toplam \\
\hline İssletme 1 & 75 & 25 & 10 & 2 & 6 & 118 \\
\hline İsletme 2 & 18 & 15 & 31 & 10 & 3 & 77 \\
\hline İşletme 3 & 6 & 23 & 11 & 4 & 5 & 49 \\
\hline İssletme 4 & 17 & 7 & 15 & 1 & 7 & 47 \\
\hline İşletme 5 & 21 & 16 & 5 & 2 & 2 & 46 \\
\hline İşletme 6 & 24 & 15 & 2 & 2 & 1 & 44 \\
\hline İşletme 7 & 7 & 7 & 2 & 1 & 1 & 18 \\
\hline İşletme 8 & 9 & 4 & 3 & 1 & 1 & 18 \\
\hline İssletme 9 & 7 & 7 & 1 & - & - & 15 \\
\hline İsletme 10 & 3 & 4 & 5 & 3 & - & 15 \\
\hline İşletme 11 & 7 & 3 & 2 & - & - & 12 \\
\hline İssletme 12 & 8 & 3 & - & - & - & 11 \\
\hline İşletme 13 & 2 & - & - & - & - & 2 \\
\hline Toplam & 204 & 129 & 87 & 26 & 26 & 472 \\
\hline \% & 43,3 & 27,3 & 18,4 & 5,5 & 5,5 & 100 \\
\hline
\end{tabular}

İçerik analizi sonucunda elde edilen e- şikâyet unsurları; yiyecek-içecek, odalar, otel genel özellikleri, çalışan davranışı, diğer otel hizmetleri ve fiyat olmak üzeri altı tema ve 45 şikâyet unsurudur. Elde edilen bulgular Tablo 2' de yer almaktadır. Buna göre en fazla şikâyet unsurunun yer aldığı temalar sırası ile yiyecek-içecek (\%39), odalar (\%23) ve otel genel özellikleridir (\%15).

Tablo 2. E-Şikâyet Unsurlarının Temalara Göre Dağılımı

\begin{tabular}{|l|l|l|l|l|l|}
\hline Tema & Sayı & $\mathbf{\%}^{*}$ & Tema & Sayı & $\mathbf{\%}^{*}$ \\
\hline Yiyecek-İçecek & $\mathbf{8 8}$ & $\mathbf{3 9}$ & Çalş̧an Davranışı & $\mathbf{2 6}$ & $\mathbf{1 1}$ \\
\hline Kahvaltı Çeşitliliği & 22 & 25 & İlgisiz Personel & 13 & 50,2 \\
\hline Yemeklerin kalitesi & 13 & 14,7 & Misafir-Personel Iletişimi & 4 & 15,1 \\
\hline Hizmet & 12 & 13,6 & Personel Eksikliği & 3 & 11,5 \\
\hline Kahvaltı Kalitesi & 12 & 13,6 & Ĕ̆itimsiz-Deneyimsiz Personel & 3 & 11,5 \\
\hline Yemeklerin Çeşitlilï̆i & 11 & 12,5 & Güler Yüzlü Olmamak & 1 & 3,9 \\
\hline Lezzet & 4 & 4,6 & Özensiz Personel & 1 & 3,9 \\
\hline Restoran Alanı & 3 & 3,5 & Kötü Yönetim & 1 & 3,9 \\
\hline Hijyen Durumu & 3 & 3,5 & Odalar & $\mathbf{5 4}$ & $\mathbf{2 3}$ \\
\hline Hızlı Servis & 2 & 2,3 & Temizlik ve Bakım & 13 & 24,4 \\
\hline Oda Servisi & 2 & 2,3 & Tasarım & 13 & 24,4 \\
\hline Minibar & 1 & 1,1 & Koku & 11 & 20,2 \\
\hline Küçük Porsiyon & 1 & 1,1 & Oda ve Banyo Yapısı & 9 & 16,5 \\
\hline Restoran yok & 1 & 1,1 & Rezervasyon Sorunu & 4 & 7,3 \\
\hline Sağlıksız & 1 & 1,1 & Yatakların Rahat Olmaması & 3 & 5,4 \\
\hline Genel Özellikler & $\mathbf{3 5}$ & $\mathbf{1 5}$ & Özel Gün Organizasyonu & 1 & 1,8 \\
\hline Bina Yapısı & 10 & 28,3 & Diğer Otel Hizmetleri & $\mathbf{2 3}$ & $\mathbf{1 0}$ \\
\hline Konum & 10 & 28,3 & Teknik Servis & 17 & 73,9 \\
\hline Asansör & 5 & 14,1 & Olanakların Kullanılamaması & 3 & 13,2 \\
\hline Müzik & 4 & 11,5 & Alkol Tüketimi & 1 & 4,3 \\
\hline Otopark & 2 & 6,2 & Standarda Uygun Değil & 1 & 4,3 \\
\hline Ses Yalıtımı & 1 & 2,9 & Oda Servisinin Olmaması & 1 & 4,3 \\
\hline Aydınlatma & 1 & 2,9 & Fiyat & $\mathbf{4}$ & $\mathbf{2}$ \\
\hline Yönlendirme & 1 & 2,9 & Ekstra Fiyat & 2 & 50 \\
\hline Genel Temizlik & 1 & 2,9 & Yüksek Fiyat & 2 & 50 \\
\hline
\end{tabular}

*Yuvarlama yapılmıştır. 


\section{Betimsel Analiz ile Elde Edilen Bulgular Yiyecek-İçecek}

Otel işletmelerinde en fazla şikâyet edilen konu yiyecek-içecek bağlamındadır. Önemlidir ki yiyecek-içecek hizmetleri ağırlama sektörünün en önemli bileşenlerinden biridir. (Chen vd., 2018). Nitekim müşteriler için de öncelikli dikkat çeken konu yiyecek ve içecek hizmetleri olmuştur. En fazla şikâyet edilen unsurlar ise sırası ile kahvaltı çeşitliliği, yemeklerin kalitesi, yiyecek-içecek hizmeti, kahvaltı kalitesi ve yemeklerin çeşitliliği ile ilgilidir. Konu ile ilgili şikâyet örnekleri aşağıda yer almaktadır.

Açık büfe kahvaltı çok yetersizdi. Neredeyse hiçbir şey yoktu. Aşırı tuzlu peynirler ve zeytinler yüzünden yumurta yiyip kalkmak zorunda kaldık. Ekmek tek çeşitti. Hamur işi yoktu. Reçel bile hazır kaplardaydı...

Kahvaltıda 6 çeşit peynir varsa 5'i tuzdan yenmiyor ama kimse de bu peyniri suda bekletelim demiyor. Akşam yemekleri için de sürekli aynı yemekler yapılıyor ama bu yemeklerin de birç̧ŏ̆u kötü. Bu konuda büyük sıkıntı çektim keyifle yemek yediğim günler sinırlıdır.

....akşam yemeği felaketti. Tüm grubumuza gelen yemek buz gibi soğuktu. Buz gibi bir yemek koydular önümüze. Yemeğini geri yollayıp ısıtılıp gelmesini isteyenlere gelen yemeğin ise yarısı yanıktı.

... yemek açık büfe değildi, çorbası, ana yemeği, cacık ve meyveden ibaretti.

Akşam otelde yemek yiyeyim dedim ve kremalı mantar ve tavuklu makarna söyledim. Gelen makarnanın içindeki tavuklar, yediklerim arasında en kötüsüydü. Hem çok sert, hem inanılmaz bir koku vardı. Krema deseniz pişmiş yemeğe döküp karıştırıp getirmişler. Yemeden olduğu gibi geri verdim.

...personel yemek biterken, içecek servisine geçti.

\section{Odalar}

Bu bölümde kat hizmetleri ve ön büro hizmetleri ile ilgili şikâyetler değerlendirilmiştir. Odaların ve banyoların tasarımı, temizlik ve bakımı, kokusu ve yapısı ile ilgili şikâyet unsurlarının sık yer aldığı görülmüştür. Bununla birlikte müşterilerin bazıları rezervasyon ile ilgili sorun yaşadıklarını belirtmişlerdir.

...Odalarda sigara içilebiliyor maalesef. Benim gibi sigara içmeyen insanlar için sürekli sigara kokusu alıp rahatsız olabilirsiniz. En azından bir kat, sigara içilmeyen odalara ayrılmalı.

Oda temizliği yetersiz. Yastıklarda ter kokusuna benzer kokudan dolayı uyuyamadım.

...Tek kelimeyle kötü. Rahat uyuyamama, eski mobilya kullanma, üzerinize sigara kokusunun sinmesi...

...eskimiş çarşaftan tutunda yastığına kadar her şey... Odalar ve mobilyalar eskimiş...

Odaları ve özellikle banyosu kullanışsız. Banyoda sadece başınızı yıkayabiliyorsunuz, sadece duş başlı̆̆ı var ve hemen hemen tüm metal şeyler paslanmış.

...yer ayırtık, üstüne konaklamadan iki günü önce teyit ettik odayı satmamaları için fakat odayı satmışlar ve hiç oda kalmadığını söyleyerek bizi ortada bıraktılar...

\section{Genel Özellikler}

Otelin genel özellikleri ilgili şikâyetler incelendiğinde en fazla şikâyet unsurlarının otelin bina yapısı, konumu, asansör ve müzik ile ilgili olduğu görülmektedir. Özellikle otel binasının eski olması dikkat çekici bir şikâyet konusu olmuştur. Otel konumunun merkeze uzaklığı ise ayrıca sorun olarak belirmiştir. 
Yenilenmesi gerekiyor baya eski.

Yeni bir otel ve şehir merkezine uzak tarlaların ortasında ve görevliler yazın çok sivrisinek olduğunu söylediler.

Otelde iki asansör bulunmakta; biri müşteri diğeri servis asansörü. Ĕ̆er gruplara denk gelirseniz asansörler yetersiz olduğundan bekleme süreniz uzayabilmektedir.

Restoranda müzik sesi abartıl olmasa daha keyifli bir konaklama olacaktt.

\section{Çalışan Davranışı}

Çalışan davranışları müşteri memnuniyetinde ve deneyiminde önemli değişkenlerden biridir (Alhelalat vd., 2017). Çalışan davranışı ile ilgili en fazla şikâyet unsurları; çalışanların ilgisiz olması ve müşterilerle olan iletişim şekilleri olmuştur.

Odaya çıkınca çantamın olmadığını fark ettim. Yemekte unutmuş olabilirim diye aşă̆̆ indim. Görevlilere sordum hiç oralı olmadılar. Burada olsa bulunurdu, kesin başka yerde unuttunuz falan dediler. İlgilenmediler.

...akşam öğ̈̈nü için tuz, su, peçete bile tek tek istememizle geldi.

...bir çalışan sanki kaçıyormuşuz gibi bir eda ile arkamızdan "ayrılıyor musunuz" dedi. Yok diye seslendik ama ne tavrı ne beden dili hoş değildi. Neden haber vermediğimiz için bizi suçlar gibi konuştular.

\section{Diğer Otel Hizmetleri}

Diğer otel hizmetleri ile ilgili şikâyetler incelendiğinde en fazla şikâyet konuları teknik servis, SPA ve hamam gibi otel olanaklarının kullanılmaması olmuştur. Teknik servis bağlamında ise sıcak su kullanımı ve klima ile ilgili sorunlar önemli görülmüştür.

Otelde fitness salonu varmış fakat kapal, havuz dışarda kışın kullanılmıyor.

Sauna güzel fakat duşlar sıkıntıll, su ısınmıyor.

...otelde sıcak bir duş alamadım ve ilgilenen de olmadı.

...ş̧̈yle sıcak su ile bir güzel duş alayım diye heveslenmeyin çünkü biz sıcak su bulamadık. Yoktu. Ilık su ile elimizi ayă̆ımızı yıkadık, duş alamadık.

...Adıyaman gibi sıcak bir memlekete geldiğimde serin bir oda istemiştim. Klima çalışıyor olsa da soğutmuyordu; dışarıdaki sıcaklikla odanın havası aynı sayılırdı.

\section{Fiyat}

En az şikâyet içeriğine sahip tema fiyat olmuştur. Hizmetin karşılığını alamama ve ekstra ücret alınması müşterileri rahatsız eden konular arasında yer almıştır. Fiyat, müşteri memnuniyetinde önemli bir faktördür (Giannakos vd., 2014). Özellikle hassas müşteriler için önemli olan fiyat faktörü, yöneticiler açısından da dikkat edilmesi gereken bir değişken olmaktadır (Sholahuddin ve Wardani, 2017).

...Yemek sonrası çay içmek istediğimizde de bara gidip kendimizin, parayla alabileceğimizi söylediler. 


\section{Geri Dönüşler}

Alrawadieh ve Dincer (2019) ile Ak ve Kızılırmak (2019) çalışmalarında e-şikâyetlere verilen yanıtların içeriğini araştırmışlardır. Yazarlar, e-şikâyetlere verilen yanıtların içeriğini dört gruba ayırmıştır. Bu çalışmada da e-şikâyetlere verilen yanıtlar incelenmiştir. Yorumları bulunan 13 otel işletmesinden $4^{\prime}$ ünün e-şikâyetlere geri dönüş yaptığı görülmüştür. E-şikâyetlere yönelik geri bildirimlerin içerik dağılımı Tablo 3' de yer almaktadır.

Tablo 3. E-Şikâyetlere Yönelik Geri Bildirimlerin İçerik Dağılımı

\begin{tabular}{|l|l|l|}
\hline Cevaplayıcı & Sayı & $\mathbf{\%}^{*}$ \\
\hline Genel Müdür & 33 & 67,3 \\
\hline Önbüro Müdürü & 13 & 26,5 \\
\hline Halkla İlişkiler Müdürü & 2 & 4,1 \\
\hline Eski çalışan & 1 & 2,1 \\
\hline Toplam & 49 & 100 \\
\hline İçerik & Sayı & $\%^{*}$ \\
\hline Teşekkür etme & 38 & 77,5 \\
\hline Şikâyet konularını ele alma & 31 & 63,2 \\
\hline Özür dileme & 23 & 46,9 \\
\hline
\end{tabular}

*Yuvarlama yapılmıştır.

Elde edilen bulgulara göre e-şikâyetlerin \%35'ine dönüş yapıldığı ve geri dönüşlerinin büyük çoğunluğunun genel müdürler tarafından yapıldığı görülmüştür. Geri dönüşlerin büyük çoğunluğunda müşterilere yorumları için teşekkür edildiği, şikâyetlerinin üzerinde durulduğu ve ilgili departmanlarla iletişime geçildiği ile ilgili bilgi verildiği görülmüştür.

\section{SONUÇ ve ÖNERILER}

Hizmet sektöründe artan rekabet ve bilgi teknolojilerindeki hızlı ilerlemeler, müşteri davranışlarında daha değişken bir görüntü ortaya koymaktadır. Bu durum otel işletmeleri açısından müşteri memnuniyetini keskin ve hassas bir boyuta taşımaktadır (Dinçer ve Alrawadieh, 2017). Günümüz otel işletmelerinin müşterilerin özellikle etkileşimi yüksek çevrimiçi yorumlarını dikkate alması kurumsal başarı için son derece önemli görülmektedir. Nitekim deneyimlenmiş bir yorum aynı zamanda potansiyel müşterilerin karar alma süreçlerini şekillendirebilmektedir (Bayram, 2018:356). Bu durum özellikle, coğrafi alg1 ve turistik gelişme düzleminde istenilen konumda olmayan Adıyaman gibi destinasyonlar için farklı bir anlam taşımaktadır (Çalışkan, 2015; Çalışkan vd., 2017). Moilanen ve Rainisto'ya (2009) göre, bir yerin ne ifade ettiği ve müşterinin bundan ne anladığı kısaca o yere ait zihninde oluşan imajı tercihlerinde genel bir kanı oluşturmaktadır. Dahası mesafe ve erişebilirlik gibi coğrafi bileşenler, müşteri tercihlerini şekillendiren bütünleyici faktörler olmaktadır (Akdag ve Oter, 2011). Bu yüzden turistik rekabet ve gelişme paydasında eli zayıf olan bölgelerdeki otellerin ayrıca çaba göstermesi ve sektörel kalite inşası zorunlu görülmektedir.

Araştırma sonucunda en fazla şikâyet unsurunun otel işletmelerinin yiyecek-içecek, odalar ve genel özellikleri ilgili olduğu görülmüştür. Bu sonuç Çulha vd. (2009) ile Kızıldemir vd.'nin (2019) araştırma sonuçları ile benzerlik göstermektedir. Yiyecek-içecek ile ilgili en fazla şikâyet edilen unsurlar, kahvaltının ve akşam yemeğinin yeterli kalite düzeyinde ve çeşitte olmamasıdır. Özellikle, Adıyaman gibi farklı coğrafya ve otantik bir kültür içinde konumlanmış otellerin yöresel yiyecekleri, müşterilerine yansitabilmesi gerekmektedir. Cardoso vd.'ne (2019) göre, yöresel yiyecekler o bölgenin kültürünü yansıtan değerler olmaktadır. Benzer şekilde Zhang 
(2009), yiyecek-içecek hizmetlerinin, turistler için sunulan temel bir hizmet olmanın ötesinde yerel kültürün eşsiz ve özgün bir ifadesi olduğunu vurgulamaktadır. Hatta birçok ziyaretçi için yöresel yiyeceklerin tüketim mekânları başlıca seyahat nedenlerinden biri haline gelmiştir (Hall ve Sharples, 2003; Walter, 2017). Dolayısıyla otel yöneticilerinin yöresel yiyecek sunumları ile ürün çeşitliliğini arttırmaları ve coğrafi özgünlüğe atfen aynı zamanda bir cazibe unsuru oluşturmaları gerekmektedir.

Odalar ile ilgili şikâyetler, araştırmadan çıkan önemli bir sorun olmuştur. Müşteriler odalar ve banyolar ile ilgili olarak en çok temizlik ve bakımı, oda tasarımı ve odalarda yer alan sigara ve ter kokusundan şikâyetçi olduklarını belirtmişlerdir. Bu bulgu, Genç ve Batman'ın (2018) çalışma bulgularıyla örtüşürken, bir başka çalışmada Alananzeh (2017), otel banyolarının ve oda mobilyalarının temizliğinden memnun olmadıklarını ortaya koymuştur. Yazar bu noktada otelde konaklayan müşteriler için hijyenin memnuniyet düzeyini etkileyen önemli bir faktör olduğunu vurgulamıştır. Buradan hareketle çalışanlara zorunlu hijyen eğitimi verilmesi ve edinilen bilgilerin pratikte nasıl kullanıldığının kontrol edilmesi gerekmektedir (Czarniecka-Skubina ve Skwierczyński, 2007).

Oda tasarımında daha çok mobilyaların eski olması dikkat çekmektedir. Bununla birlikte oda ve banyo yapısının küçüklüğü ile ilgili yorumlar yapılmıştır. Fiziki görünüm açısından önemli görülen bir diğer şikâyet unsuru ise otelin dış mekân yapısının eski olması ile ilgilidir. Lee (2011), otel mimarisinin cazibe unsuru olabileceğini ifade ederken, Breazeale ve Ponder (2013), mimari yapının müşterilerle bir iletişim şekli olduğundan bahsetmektedir. Bu noktada otel işletmelerinin bir cazibe unsuru yaratabilmeleri amacıyla binaların dış mekân tasarımını yenilemeleri gerekirken tasarımda bulunduğu coğrafyanın simgelerini veya kültürünün motiflerini kullanmaları faydalı olacaktır.

Otel işletmelerinin konumunun merkezi olmama durumu bir başka şikâyet konusu olurken, Adıyaman il merkezinde yeteri sayıda nitelikli otel işletmesinin olmaması bu duruma zemin hazırlamıştır. Shoval'a (2006) göre, otellerin coğrafi konumlanış örüntülerini pazarlama açısından önemli görmektedir. Dolayısıyla özellikle otantik coğrafyalarda bulunan otellerin konum seçiminde yöresel alışveriş ve eğlence mekânları gibi merak uyandıran tamamlayıcı unsurlara yakınlık önem arz etmektedir.

Kızıldemir vd.'nin (2019) yapmış oldukları çalışmada çalışan davranışı ve teknik problemler hizmet kalitesinin arttırılmasında önemli görülen şikâyet unsurlarıdır. Benzer şekilde bu çalışmada, çalışanların ilgisiz olması ve su, klima gibi yaşanan teknik sorunlar müşterilerin önemli gördükleri sorunlardır. Açıkçası turizm sektöründe çalışan-müşteri ilişkisi ana eksende yer alırken çalışan davranışlarının müşteri memnuniyetini etkilediği (Akova ve Işık, 2008; Erkuş ve Günlü, 2009) bilinmektedir. Dolayısıyla otel yöneticilerin yapılan bu şikâyetleri dikkate alarak çalışanların eğitilmesi ve teknik sorunların giderilmesi noktasında önlem almaları gerekmektedir.

Araştırma sonuçlarının bir ayağı da müşteri şikâyetlerine yapılan geri dönüşler ile ilgilidir. Yapılan analizlerde otel yönetimlerinin geri dönüşlerinin oldukça az olduğu saptanmıştır. Nitekim Alrawadieh ve Demirkol (2015), e-şikâyetlere verilen yanıt oranın genellikle düşük olduğunu ve verilen yanıtlarda ise çoğunlukla kalıp cümlelerin kullanıldığını vurgulamıştır. Burada önemli husus, kurumsal bir genel geçerlilikten öte; Adıyaman coğrafyasının özelinde yöresel misafirperverliğin gösterilmesidir. Benzer söylemle misafirlerin kendilerini daha özel hissetmelerini sağlamak esasında, memnun olmayan müşterilerin şikâyetlerine geri dönüşler yaparak işletme hakkında olumlu tutum kazandırmak (Alrawadieh ve Dinçer; 2019) gerekmektedir. 
Son olarak, gelişen teknoloji ile birlikte şikâyetlerin sosyal ağlardaki güçlü etkileşimi potansiyel müşterilerin satın alma davranışlarını öncelemektedir. Söz konusu şikâyetler, her ne kadar olumsuz olarak algılansa da hataların geri dönüşümünde bir çerçeve oluşturmaktadır.

Bununla birlikte Adıyaman'daki otel işletmelerinde geceleme sayısının az olmasından dolayı müşteri şikâyetlerinin telafisi zor olmaktadır. Bu noktada otel yöneticilerinin ve çalışanların Trip Advisor gibi etkileşimi yüksek seyahat sitelerinde yer alan şikâyetlerin takibini yapması, geri dönüşlerin sağlanması ve gereken adımların somut düzlemde atılması gerekmektedir.

Elbette bu araştırmanın sonuçları, kendine özgü coğrafyası olan Adıyaman özelinde değerlendirilmelidir. Sonraki çalışmalar için benzer potansiyele sahip farklı destinasyonların karşılaştırmalı olarak ele alınması önerilebilir.

\section{KAYNAKÇA}

Alananzeh, O. (2017). The Impact of Safety Issues and Hygiene Perceptions on Customer Satisfaction: A Case Study of four- and five-Star Hotels in Aqaba, Jordan, J Tourism Res Hospitality, 6(1): $1-7$.

Alhelalat, J. A., Ma'moun, A. H. and Twaissi, N. M. (2017). The Impact of Personal and Functional Aspects of Restaurant Employee Service Behaviour on Customer Satisfaction, International Journal of Hospitality Management, 66: 46-53.

Alrawadieh, Z. ve Demirkol, Ş. (2015). Konaklama İşletmelerinde E-Şikâyet Yönetimi: İstanbul'daki Beş Yıldızlı Oteller Üzerinde Bir Çalışma, Nişantaşı Üniversitesi Sosyal Bilimler Dergisi, 3 (1): 132-151.

Alrawadieh, Z. and Dincer, M.Z. (2019). Reputation Management in Cyberspace: Evidence from. Jordan's Luxury Hotel Market, Journal of Hospitality and Tourism Technology, 10 (1): 107-120.

Ak, S. ve Kızılırmak, İ. (2019). Otel İşletmelerinde E-Şikâyetler ve E-Şikâyet Yönetimi Üzerine Bir Araştırma, Türk Turizm Araştırmaları Dergisi, 3(4): 820-832.

Akan, Y. ve Kaynak, S. (2008). Tüketicilerin Şikâyet Davranışını Etkileyen Faktörler, Ankara Üniversitesi SBF Dergisi, 63 (2): 1-19.

Akdag, G. and Oter, Z. (2011). Assessment of World Tourism from a Geographical Perspective and A Comparative View of Leading Destinations in the Market, Procedia-Social and Behavioral Sciences, 19: 216-224.

Akova ve Işık, (2008). Otel İşletmelerinde Stres Yönetimi: İstanbul'daki Beş Yıldızlı Otel İşletmelerinde Bir Araştırma, Kocaeli Üniversitesi Sosyal Bilimler Enstitüsü Dergisi, 15(1): 17-44.

Arpacı, Ö. (2016). Seyahat Acentalarının Tur Hizmetlerine Yönelik Müşteri E-Şikâyetlerinin Örgütsel Öğrenme Aracı Olarak Değerlendirilmesi, İstanbul Ticaret Üniversitesi Sosyal Bilimler Dergisi, 15 (29): 203-219.

Bayram, M. (2018). Otel Memnuniyetini Etkileyen Unsurlar, Seyahat ve Otel İşletmeciliği Dergisi, 15 (2): 352-369.

Braun, V., and Clarke, V. (2006). Using thematic analysis in psychology. Qualitative Research in Psychology, 3(2), 77-101.

Breazeale, M., and Ponder, N. (2013). Get the picture? Visual Servicescapes and Self-Image Congruity, Journal of Business Research, 66(7), 839-846. 
Broadbridge, A. and Marshall, J. (1995). Consumer Complaint Behavior: The Case of Electrical Goods, International Journal of Retail \& Distribution Management, 23 (9): 8-18.

Buhalis, D. and Law, R. (2008). Progress in Information Technology and Tourism Management: 20 Years on and 10 Years after the Internet-The State of e-Tourism Research, Tourism Management, 29: 609-623.

Cai, L. A. and Hobson, J. P. (2004). Making Hotel Brands Work in a Competitive Environment, Journal of Vacation Marketing, 10(3): 197-208.

Cardoso, L., Araújo Vila, N., de Araújo, A.F. and Dias, F. (2019). Food Tourism Destinations' Imagery Processing Model, British Food Journal, available at: https://doi.org/10.1108/BFJ-08-20180557.

Chan, G.S.H., Hsiao, A. C. H. and Lee, A. L. Y. (2016). Exploration of Customer Compliant Behavior toward Asian Full-Service Restaurants, International Journal of Marketing Studies, 8(2): 46.

Chang, Y. C., Ku, C. H. and Chen, C. H. (2019). Social Media Analytics: Extracting and Visualizing Hilton Hotel Ratings and Reviews from TripAdvisor, International Journal of Information Management, 48: 263-279.

Chen, J., Wang, J., Baležentis, T., Zagurskaitė, F., Streimikiene, D. and Makutėniené, D. (2018). Multicriteria Approach towards the Sustainable Selection of a Teahouse Location with Sensitivity Analysis, Sustainability, 10(8): 2-17.

Crie, D. (2003). Consumers' Complaint Behaviour. Taxonomy, Typology and Determinants: Towards a Unified Ontology, Journal of Database Marketing \& Customer Strategy Management, 11(1): 60-79.

Czarniecka-Skubina, E. and Skwierczynski, S. (2007). Examination of Hygiene Knowledge of Personnel Employed in Hotel Catering Establishments, Polish Journal of Food and Nutrition Sciences, 57 (4 [A]): 95-99.

Caliskan, C. and Dedeoglu, B. B. (2018). Human Geography and Branding in Small Destinations: A Case Study of Adıyaman, Asia Pacific Journal of Tourism Research, available at: https://doi.org/10.1080/10941665.2018.1544157.

Çalışkan, C. (2015). Turizm Potansiyeli Olan Bölgelerin Kalkınma Sürecinde Toplumsal Kapasiteyi Güçlendirme Stratejileri: Adıyaman Örneği, Yayınlanmamış Doktora Tezi, Nevşehir Hacı Bektaş Veli Üniversitesi Sosyal Bilimler Enstitüsü, Nevşehir.

Çalışkan C. Yeşilyurt H., Yeşilyurt, C. (2017). Marka Otel? Adıyaman'da Bir Araştırma, I. Uluslararası Turizmin Geleceği Kongresi: İnovasyon, Girişimcilik ve Sürdürebilirlik Kongresi (Futourism 2017), Mersin Üniversitesi 28-30 Eylül. Mersin. ss: 1028-1036.

Çakıcı, C. ve Güler. O. (2015). Şikâyet Yönetimi. B. Kılıç ve Z. Oter (Ed.), Turizm Pazarlamasında Güncel Yaklaşımlar (s. 217-251) içinde. İstanbul: Beta Basım Yayım Dağıtım.

Çulha, O., Hacıoğlu, G. ve Kurt, G. (2009). Otel Müşterilerinin E-Şikâyetlerine Yönelik Bir İçerik Çözümlemesi, Seyahat ve Otel İşletmeciliği Dergisi, 6(4): 42-49.

Dalgıç, A., Güler, O. ve Birdir, K. (2016). Tripadvisor.com'da Yer Alan Restoran Şikâyetlerinin Analizi: Mersin ve Hatay'da Yöresel Yiyecek Sunan Restoranlara Yönelik Bir Araştırma, Journal of Tourism and Gastronomy Studies, 4 (Special Issue 1): 153-173.

Dincer, M.Z. and Alrawadieh, Z. (2017). Negative Word of Mouse in the Hotel Industry: A Content Analysis of Online Reviews on Luxury Hotels in Jordan, Journal of Hospitality Marketing and Management, 26 (8): 785-80. 
Doğancili, O, S., Karaçar, E. ve Ak, S. (2019). Göller Bölgesi'nde Yer Alan Otel İşletmelerinin Tripadvisor'daki Tüketici Değerlendirmeleri Üzerine Bir Araştırma, Uluslararası Türk Dünyası Araştırmaları Dergisi, 4 (1): 96-106.

Erdem, B. (2010). Otel Endüstrisinde Yeni Bir Trend: Dizayn Oteller, Journal of Commerce, 1, 115132.

Erkuş, A. ve Günlü, E. (2009). İletişim Tarzının ve Sözsüz İletişim Düzeyinin Çalışanların İş Performansına Etkisi: Beş Yıldızlı Otel İşletmelerinde Bir Araştırma, Anatolia: Turizm Araştırmaları Dergisi, 20(1): 7-24.

Fernandes, T. and Fernandes, F. (2018). Sharing Dissatisfaction Online: Analyzing the Nature and Predictors of Hotel Guests Negative Reviews, Journal of Hospitality Marketing \& Management, 27(2): $127-150$.

Genç, K. ve Batman, O. (2018). Tarihi Konaklama İşletmelerine Yönelik E-Şikâyetlerin Değerlendirilmesi: İpek Yolu Ayaş-Sapanca Koridoru Üzerine Bir Araştırma, Uluslararası Yönetim İktisat ve İsletme Dergisi, 14 (1): 283-296.

Giannakos, M. N., Pappas, I. O. and Mikalef, P. (2014). Absolute Price as a Determinant of Perceived Service Quality in Hotels: A Qualitative Analysis of Online Customer Reviews, International Journal of Hospitality and Event Management, 1(1): 62-80.

Hackett, G. and Melia, D. (2012). The hotel as the Holiday/Stay Destination: Trends and Innovations. Presented at THRIC Conference, Belfast, Ireland - June 2012 and EuroCHRIE Conference, October 2012, Lausanne, Switzerland.

Hall, C. M. and Sharples, L. (2003). The Consumption of Experiences or the Experience of Consumption?, N. Macionis, \& B. Cambourne (Eds.), Food Tourism Around the World (pp. 1-24). New York: Routledge.

Harrison-Walker, L. J. (2001). E-Complaining: A Content Analysis of an Internet Complaint Forum, Journal of Services Marketing, 15(5): 397-412.

Heung, V. C. and Lam, T. (2003). Customer Complaint Behaviour Towards Hotel Restaurant Services, International Journal of Contemporary Hospitality Management, 15(5): 283-289.

İpekyolu Kalkınma Ajansı (IKA) (2018). “Kültür ve Turizm”. https://www.ika.org.tr/Kultur-veTurizm-icerik-76.html (erişim tarihi: 20.01.2020)

Kılıç, B. ve Ok, S. (2012). Otel İşletmelerinde Müşteri Şikayetleri ve Şikayetlerin Değerlendirilmesi, Journal of Yasar University, 25(7): 4189-4202.

Kılıç, B., Ok, S. ve Sop, S. A. (2013). Otel İşletmelerinde Müşteri Şikâyetlerinin Değerlendirilmesi ve Hizmet Kalitesi Algısının Müşteri Sadakati Üzerine Etkisi, Gaziantep University Journal of Social Sciences, 12(4): 817-836.

Kızıldemir, Ö., İbiş, S. ve Çöp, S. (2019). Afyonkarahisar'da Faaliyet Gösteren Beş Yıldızlı Otel İşletmelerine Yönelik Yapılan Yorumların ve E-Şikâyetlerin Değerlendirilmesi, Elektronik Sosyal Bilimler Dergisi, 18 (71): 1315-1324.

Kim, J. H. and Lynn, J. (2007). Classification of Asian Complainers in Restaurant Services, Asia Pacific Journal of Tourism Research, 12(4): 365-375.

Kutluk, A. ve Arpacı, Ö. (2016). E-Wom Bağlamında Seyahat Acentalarına Yönelik E-Şikâyetlerin Gömülü Teori ve İçerik Analizi ile İncelenmesi, Balıkesir Üniversitesi Sosyal Bilimler Enstitüsü Dergisi, 19 (35): 367-386. 
Kültür ve Turizm Bakanlığı (2019). Turizm Yatırım ve İşletme Belgeli Tesis İstatistikleri. https://yigm.ktb.gov.tr/TR-201136/turizm-yatirim-ve-isletme-bakanlik-belgeli-tesis-istati-.html, Erişim tarihi: 20.01.2020.

Kümbetoğlu, B. (2008). Sosyolojide ve Antropolojide Niteliksel Yöntem ve Araştırma, İstanbul: Bağlam Yayıncilık.

Lee, T. J. (2011). Role of Hotel Design in Enhancing Destination Branding, Annals of Tourism Research, 38(2), 708-711.

Moilanen, T. and Rainisto, S. (2009). How to Brand Nations, Cities and Destinations. A Planning Book for Place Branding. UK: Palgrave MacMillan, 65-75.

Ngai, E. W., Heung, V. C., Wong, Y. H. and Chan, F. K. (2007). Consumer Complaint Behaviour of Asians and Non-Asians About Hotel Services, European Journal of Marketing, 41 (11-12): 1375139.

O'Connor, P. (2010). Managing a Hotel's Image on TripAdvisor, Journal of Hospitality Marketing $\mathcal{E}$ Managing, 19: 754-772.

Oral, S. (2005). Otel İşletmeciliği ve Verimlilik Analizleri. Ankara: Detay Yayıncllık.

Özel, Ç.H. (2012). Otelcilik Endüstrisi, (Editör) Akoğlan Kozak, M.: Otel İşletmeciliği içinde (ss. 125) Ankara: Detay Yayıncilik.

Shoval, N. (2006). The Geography of Hotels in Cities: An Empirical Validation of a Forgotten model, Tourism Geographies, 8(1): 56-75.

Şener, B. (2010). Modern Otel işletmelerinde Yönetim ve Organizasyon. Ankara: Detay Yayıncılık.

Şahin, I., Gulmez, M. and Kitapci, O. (2017). E-Complaint Tracking and Online Problem-Solving Strategies in Hospitality Management, Journal of Hospitality and Tourism Technology, 8(3): 372-394.

Sholahuddin, M. and Wardani, A.K. (2017). Customer Satisfaction in Sharia Hotel. Prosiding Seminar Nasional Riset Manajemen \& Bisnis 2017: Perkembangan Konsep dan Riset E-Business di Indonesia. (pp.244-267).

Şimşek, H. (2009). Eğitim Tarihi Araştırmalarında Yöntem Sorunu, Ankara Üniversitesi Eğitim Bilimleri Fakültesi Dergisi, 42(1): 33-51.

Tronvoll, B. (2007). Customer Complaint Behaviour From the Perspective of the ServiceDominant Logic of Marketing, Managing Service Quality: An International Journal, 17(6): 601-620.

Tyrrell, B. and Woods, R. (2005). E-Complaint: Lessons to be Learned from the Service Recovery Literature, Journal of Travel \& Tourism Marketing, 17(2-3): 183-190.

Yaşar, Z. (2019). Kastamonu'da Yöresel Yiyecek İçecek Hizmeti Sunan Restoranlara İlişkin Tüketici Şikâyetlerinin Değerlendirilmesi: Tripadvisor Örneği, Safran Kültür ve Turizm Araştırmaları Dergisi, 2 (2): 241-250.

Yıldırım, A. ve Şimşek, H. (2011). Sosyal Bilimlerde Nitel Araştırma Yöntemleri. Ankara: Seçkin Yayincilik.

Yılmaz, İ. ve Çalışkan, C. (2015). Turizm Potansiyeli Olan Bölgelerde Toplumsal Kapasite Algısı: Adıyaman Örneği, Journal of Yaşar University, 10(39), 6585-6595.

Walter, P. (2017). Culinary Tourism as Living History: Staging, Tourist Performance and Perceptions of Authenticity in a Thai Cooking School, Journal of Heritage Tourism, 12(4): 365-379. 
Zhang, T. (2009). A Strategic Use of Special Event within Food Service: A Case Study of Culinary Tourism in Macao. In 2009 First International Conference on Information Science and Engineering (pp. 4145-4148).

Zeng, G., Cao, X., Lin, Z. and Xiao, S.H. (2020). When Online Reviews Meet Virtual Reality: Effects on Consumer Hotel Booking, Annals of Tourism Research, 81: 1-12. 